\title{
Evaluation of cements obtained by alkali-activated coal ash with $\mathrm{NaOH}$ cured at low temperatures
}

\author{
A. A. Hoyos-Montilla $\bowtie$, Y. P. Arias-Jaramillo, J. I. Tobón \\ Cement and Building Materials Group, Department of Materials and Minerals, Faculty of Mines, \\ Universidad Nacional de Colombia, Colombia. \\ $\triangle$ aahoyosm@unal.edu.co
}

\author{
Received 27 September 2017 \\ Accepted 19 March 2018 \\ On line first 03 September 2018
}

\begin{abstract}
The temperature at which the alkaline activation process takes place is a significant factor in the evolution of the mechanical properties of coal ash cementitious base material. In this work, the influence of temperature $\left(8 \mathrm{a} 38^{\circ} \mathrm{C}\right.$ ) and curing time ( 3 and 28 days) on the mechanical properties of the alkaline synthesis of two coal ashes was evaluated through the study of the mineralogical evolution of the cementitious phases by XRD and FTIR. We found that the type of zeolite, a synthesis product, depends on the study factors. For values above $28{ }^{\circ} \mathrm{C}$ and at least 7 days, alkalinely activated cements with compressive strength above $20 \mathrm{MPa}$ were achieved. Other parameters, such as $\mathrm{SiO}_{2} / \mathrm{Al}_{2} \mathrm{O}_{3}$ ratio, percentage of unburned coal and particle-size distribution, should be taken into account in the variation of mechanical performance.
\end{abstract}

KEYWORDS: Fly ash; Temperature; Alkali-activated cement; Particles size distribution; Compressive strength

Citation/Citar como: Hoyos- Montilla, A.A.; Arias-Jaramillo, Y.P.; Tobón, J.I. (2018) Evaluation of cements obtained by alkali-activated coal ash with $\mathrm{NaOH}$ cured at low temperatures. Mater. Construcc. 68 [332], e170 https://doi. org/10.3989/mc.2018.10117

RESUMEN: Evaluación de cementos obtenidos por activación alcalina de ceniza de carbón con NaOH curados a bajas temperaturas. La temperatura a la cual se desarrolla el proceso de activación alcalina es un factor significativo en la evolución de las propiedades mecánicas de material cementante base ceniza de carbón. En este trabajo se evaluó, a través del estudio de la evolución mineralógica de las fases cementantes por DRX y FTIR, la influencia de la temperatura $\left(8\right.$ a $38^{\circ} \mathrm{C}$ ) y tiempo (3 y 28 días) de curado sobre las propiedades mecánicas de la síntesis alcalina de dos cenizas de carbón. Se encontró que el tipo de zeolita, producto de la síntesis, depende de los factores de estudio. Para valores superiores a $28^{\circ} \mathrm{C}$ y mínimo 7 días, se lograron cementos activados alcalinamente con resistencias superiores a $20 \mathrm{MPa}$. Otros parámetros, como la relación $\mathrm{SiO}_{2} / \mathrm{Al}_{2} \mathrm{O}_{3}$, el porcentaje de carbón inquemado y la distribución del tamaño de partícula, se deben de tener en cuenta en la variación del desempeño mecánico.

PALABRAS CLAVE: Ceniza volante; Cemento activado alcalinamente; Temperatura; Distribución de tamaño de partículas; Resistencia a la compresión.

ORCID ID: A.A. Hoyos-Montilla (http://orcid.org/0000-0001-5115-7233); Y.P. Arias-Jaramillo (http://orcid.org/ 0000-0002-8988-6295); J.I. Tobón (http://orcid.org/0000-0002-1451-1309)

Copyright: (C) 2018 CSIC. This is an open-access article distributed under the terms of the Creative Commons Attribution 4.0 International (CC BY 4.0) License 


\section{INTRODUCTION}

Alkaline activation of precursors rich in $\mathrm{SiO}_{2}$ and $\mathrm{Al}_{2} \mathrm{O}_{3}$, like coal ash, is currently one of the most relevant research topics in conglomerate materials (1-5). Seen from a technical standpoint, the literature accounts for these materials great benefits in their mechanical properties and durability with respect to conventional cementitious materials, such as Ordinary Portland Cement (OPC) (6). From the environmental point of view, great benefits are also obtained by reusing industrial by-products and by being produced at temperatures around $60{ }^{\circ} \mathrm{C}(6)$, temperature, which is very low for Alkali-Activated Cements (AAC) when compared to the approximately $1500{ }^{\circ} \mathrm{C}$, which is required to produce the OPC. However, the demand for these curing temperatures means that alkali-activated cements are difficult to handle on site (7), which have been recommended primarily for precast fabrication. Curing at room temperature is very important in terms of practical application since all energy savings in building materials represent not only a lower carbon footprint, but also a lower cost.

It is clear that the temperature is linked to a substantial increase in the kinetics of any reaction. Therefore, it is expected that with increasing temperature, the development of the cementing phases during alkaline activation will be faster. It has been suggested that the increase in temperature in the process of alkaline activation is very effective in the early stages of the reaction, "hours," because it guarantees a thermal impulse for its development (6).

Some researchers assert that curing between 4 and 48 hours is one of the decisive synthesis conditions in the alkali-activated of coal ash, finding that the best development of mechanical properties occur at temperatures that oscillate around $60^{\circ} \mathrm{C}(8)$ and that when the system is cured at higher temperatures the samples lose moisture, thus increasing the number of fissures and cracks (9) and hence decreasing their compressive strength. In line with Davidovits (10) polycondensation, which is the process in which the gels that provide mechanical strength are formed, takes place at temperatures below $120^{\circ} \mathrm{C}$ with a recommended value close to $60{ }^{\circ} \mathrm{C}$. Likewise, he states that said process requires curing times, which vary according to the temperature and way of heating. An increase in temperature reduces curing times to achieve higher resistances.

According to Chithiraputhiran and N. Neithalath (11), alkali-activated of fly ash of $\mathrm{NaOH} 8 \mathrm{M}$ requires activation temperatures above $35^{\circ} \mathrm{C}$ in order to reach sufficient heat to overcome the energy barrier of activation so that they are able to form the reaction products. Showing, in this way that it is possible to activate these raw materials at temperatures below $60{ }^{\circ} \mathrm{C}$.

Therefore, although alkaline cement systems can be asserted to be thermodynamically viable at room temperature $(7,11-13)$, it is necessary to broaden the understanding of both the activation process and the behavior of the products obtained as well, in order to find methodologies, which allow further reduction of the activation temperatures.

As for other precursors, like metakaolin, researchers, such as Rovnaník (14) have evaluated their activation at temperatures ranging from $10{ }^{\circ} \mathrm{C}$ to $80^{\circ} \mathrm{C}$. He accounts that in the activation of this system in 4 hours and at temperatures of $40{ }^{\circ} \mathrm{C}$, cementing phases with mechanical characteristics of the order of $60 \mathrm{MPa}$ are formed, and on the contrary, these characteristics were delayed until approximately 4 days when the mixture was treated at a temperature of $10^{\circ} \mathrm{C}$. Temperatures higher than $40{ }^{\circ} \mathrm{C}$ presented an increase in the volume and pores size, as well.

Albeit some developments have demonstrated the feasibility of alkaline activation using metakaolin precursors at low temperatures, it is necessary to go deeper into the subject concerning coal ash activation at low temperature, since they have a different chemical composition and structure. Metakaolin is commonly considered as one of the best precursors for the production of alkali activated materials because of the high reactivity and the controlled chemical composition. Coal ashes, on the contrary, present a non-controlled composition and a lower reactivity. The Fly ash also constitutes a greater volume and a lower cost in obtaining this type of building materials.

That is why in this research, both the mechanical behavior and the mineralogical development of two alkali-activated coal ashes with $\mathrm{NaOH}$ at temperatures between $8{ }^{\circ} \mathrm{C}$ and $38{ }^{\circ} \mathrm{C}$ were evaluated. These temperatures are regular at room temperature, in many parts around the world.

\section{MATERIALS AND METHODS}

\subsection{Materials}

Two ashes from coal combustion were used. One comes from the thermoelectric process of the textile industry (CT) and the other one comes from the heating of boilers in the paper industry (CP). The chemical composition, determined by X-Ray Fluorescence (XRF) on Phillips PW 2400 equipment, is shown in Table 1.

The silica/alumina molar ratio is 1.47 and 1.43 for $\mathrm{CT}$ and $\mathrm{CP}$ ash, respectively. CT features higher contents of silica, alumina, and iron oxides and smaller loss on ignition than the CP ash. The LOI are mainly associated with the unburned coal contained in the samples.

The particles size distribution (PSD) of ashes (Figure 1) was measured in Master Sizer 3000 equipment. $\mathrm{A}_{80}$ of $28 \mu \mathrm{m}$ for $\mathrm{CT}$ and $45 \mu \mathrm{m}$ for $\mathrm{CP}$ is presented. A bimodal distribution in CT with 
TABLE 1. Chemical composition of coal ashes (\% wt)

\begin{tabular}{lcccccccc}
\hline Sample & $\mathbf{S i O}_{2}$ & $\mathbf{A l}_{2} \mathbf{O}_{3}$ & $\mathbf{F e}_{2} \mathbf{O}_{3}$ & $\mathbf{C a O}$ & $\mathbf{M g O}$ & $\mathbf{N a}_{2} \mathbf{O}$ & $\mathbf{S O}_{3}$ & $\mathbf{L O I}^{*}$ \\
\hline $\mathbf{C T}$ & 46.20 & 31.40 & 4.75 & 4.46 & 1.82 & 3.63 & 0.68 & 3.90 \\
$\mathbf{C P}$ & 40.50 & 28.30 & 2.24 & 5.97 & 1.52 & 5.91 & 0.60 & 10.77 \\
\hline
\end{tabular}

*Loss on Ignition from $110^{\circ} \mathrm{C}$ to $1000^{\circ} \mathrm{C}$

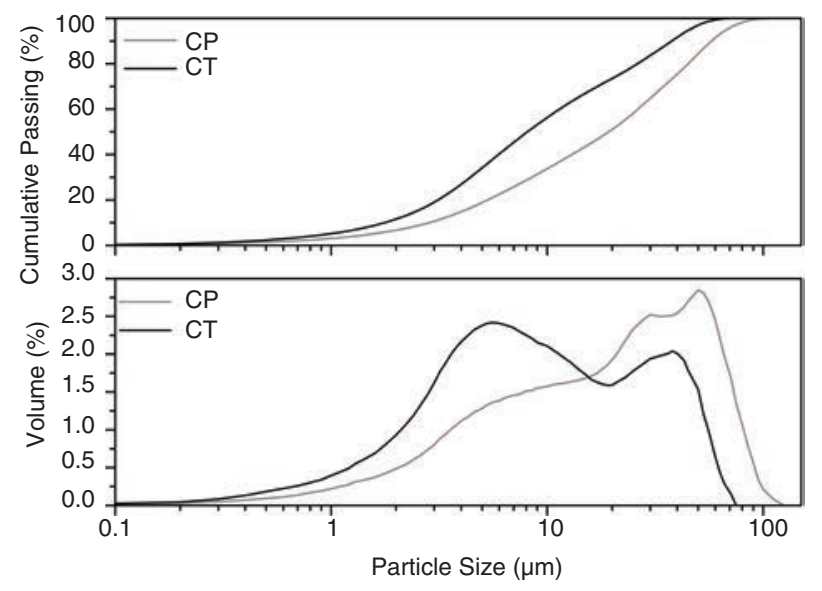

FIGURE 1. Particles size distribution for coal ashes.

modes in $5 \mu \mathrm{m}$ and $40 \mu \mathrm{m}$ can also be observed. The PSD for $\mathrm{CP}$ is much more open with concentrations in $7 \mu \mathrm{m}, 30 \mu \mathrm{m}$, and $50 \mu \mathrm{m}$. Hence, showing $\mathrm{CT}$ as the finest ash.

The mineralogical content of the ashes was determined by X-Ray Diffraction (XRD) on a PANalytical X'Pert MPD PRO equipment, with $\mathrm{CuK}_{\alpha 1}(\lambda=1.54059 \AA)$ source, the X-Ray tube was worked at $45 \mathrm{kV}$ and $40 \mathrm{~mA}$. Data were collected from $5^{\circ}$ to $70^{\circ}$ for 2 hours. For the quantification phase, $75 \%$ coal ash mass and $25 \%$ in mass of internal pattern of $\mathrm{Al}_{2} \mathrm{O}_{3}(99.99 \%$ purity, Sigma-Adrich, St. Louis, MO, USA) were used. The quantification of the phases was carried out by the Rietveld method using a GSAS Software, as well as the pseudo-Voigt type peak-shape fit function, with asymmetry correction. The parameters used for the refinement were Background coefficients, unit cell parameters, zero change error, peak shape parameters and phase fraction. As it is shown in Table 2, the two ashes have similar mineralogies composed of mullite, quartz, hematite, and mainly amorphous phases. CT features a higher percentage of amorphous phases.

TABLE 2. Relation of phases in coal ash

\begin{tabular}{lccccc}
\hline Sample & $\begin{array}{c}\% \\
\text { Mullite }\end{array}$ & $\begin{array}{c}\% \\
\text { Quartz }\end{array}$ & $\begin{array}{c}\% \\
\text { Hematite }\end{array}$ & $\begin{array}{c}\text { \% Amorphous } \\
\text { phase }\end{array}$ & $\begin{array}{c}\% \\
\text { Others }\end{array}$ \\
\hline CT & 17.49 & 9.01 & 1.59 & 72.25 & 0.00 \\
CP & 13.77 & 11.22 & 1.02 & 70.91 & 3.08 \\
\hline
\end{tabular}

\subsection{Experimental procedure}

Each of the ashes was activated with a $\mathrm{NaOH}$ solution with a concentration of $8 \mathrm{M}$, prepared from flakes at $98 \%$ purity, maintaining a constant liquid/solid (1/s) of 0.28 .

Ash-based cement pastes were prepared in consonance with ASTM C 305 standard. For the mechanical tests, cylindrical molds of PolyVinyl Chloride (PVC) 1 inch in diameter and the aspect ratio 1:2 were used. The specimens were emptied in three layers; each layer compacted 75 times on the compacting table in accordance with UNE EN 231 standard. Once the paste was emptied into the molds, it was placed in vacuumsealed polypropylene bags and, subsequently, dipped into water, at temperatures of $8^{\circ} \mathrm{C}, 18^{\circ} \mathrm{C}$, $28^{\circ} \mathrm{C}$, and $38^{\circ} \mathrm{C}$ for curing. The specimens were extracted and evaluated at ages 1, 3, 7, 14, and 28 days.

Cured pastes at different temperatures and ages were analyzed mineralogically by X-Ray Diffraction (XRD) in a PANalytical X'Pert MPD PRO between $5^{\circ}$ to $60^{\circ}$ with step size of $0.02^{\circ}$ and counting time of 56 seconds. $\mathrm{A} \mathrm{CuK}_{\alpha 1}(\lambda=1.54059 \AA)$ source was used.

The functional groups were evaluated by means of a Fourier Transform Infrared Spectroscopy (FTIR), on a SHIMADZU FTIS-8400S spectrometer, in transmission mode and using $\mathrm{KBr}$ pellets. Infrared absorption spectra were measured from $400 \mathrm{~cm}^{-1}$ to $4000 \mathrm{~cm}^{-1}$ with 64 numbers of scans and $4 \mathrm{~cm}^{-1}$ of resolution.

The heat flow during alkaline activation was evaluated by means of isothermal conduction microcalorimetry. A TAM Air micro-calorimeter from TA instruments of isothermal principle was used with air thermostat at $18^{\circ} \mathrm{C}, 28^{\circ} \mathrm{C}$ and $38^{\circ} \mathrm{C}$. The samples were filled into glass ampoules and were sat inside the kit for 40 minutes to achieve thermal stability. Then, the liquid portion of the samples was injected using an admix device, which was mixed for two minutes. Reading up to 800 hours for $18{ }^{\circ} \mathrm{C}, 350$ hours for $28^{\circ} \mathrm{C}$ and 80 hours for $38^{\circ} \mathrm{C}$ was carried out.

The chemical composition was obtained by means of XRF on a Phillips PW 2400 X-ray fluorescence spectrometer. The test was carried out on pressed powder ash. 


\section{RESULTS}

\subsection{Identification by XRD}

Figure 2 and Figure 3 show the diffractograms for the coal ashes evaluated along with their corresponding mineralogical evolution over time after being activated at different temperatures. Phases with amorphous characteristics, crystalline phases coming from ashes, such as quartz (PDF 00-0010649), mullite (PDF 00-001-0613), and hematite (PDF 00-024-0072), as well as phases of zeolitic nature, which were developed during activation process, such as sodalite, which were identified in them.

The type of zeolite that crystallizes depends on both the time and temperature of the curing. Hydrated sodalite (S), also known as hydroxysodalite

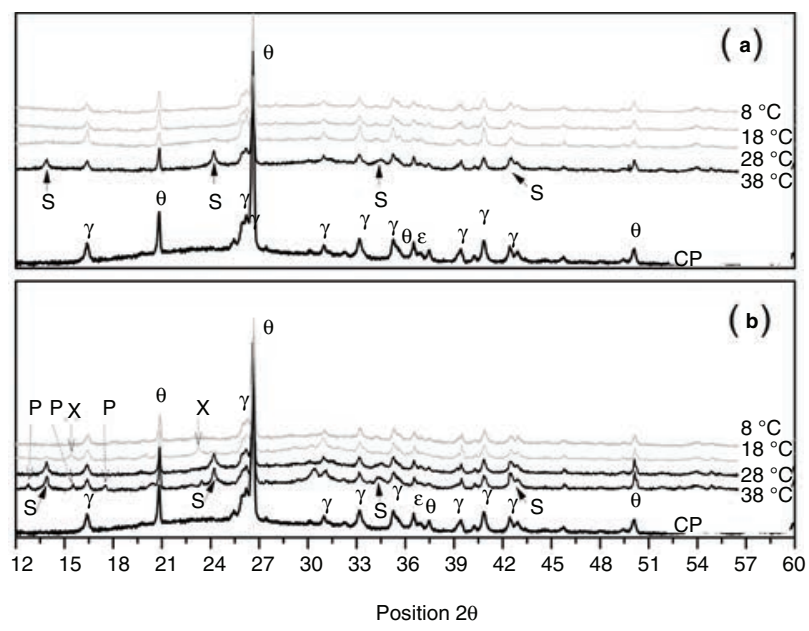

Figure 2. Diffractograms of the CP ash (a) 3 days and (b) 28 days of curing. $\theta$ : Quartz, $\gamma$ : Mullite, $\varepsilon$ : Hematite, S: Sodalite, P: Zeolite Phi, X: Zeolite X.
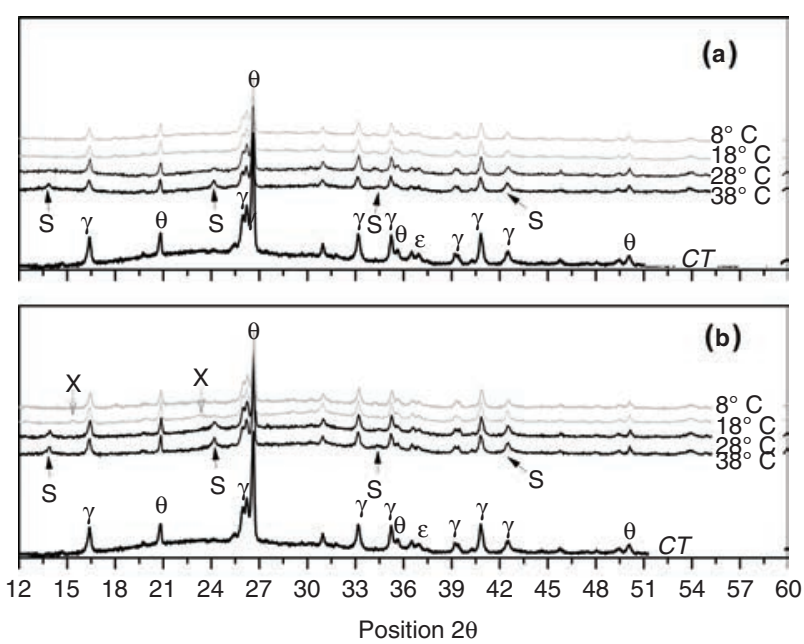

FIGURE 3. Diffractograms of CT ash (a) 3 days and (b) 28 days of curing. $\theta$ : Quartz, $\gamma$ : Mullite, $\varepsilon$ : Hematite, S: Sodalite, X: Zeolite X. type $\mathrm{Na}_{4} \mathrm{Al}_{3} \mathrm{Si}_{3} \mathrm{O}_{12} \mathrm{OH}$ (PDF 00-011-0401), was detected in the alkaline synthesis of both coal ashes from 3 days to 28 days when the systems were activated at $38{ }^{\circ} \mathrm{C}$. In this type of zeolite, the $\mathrm{Si} / \mathrm{Al}$ is close to the unity indicating an $\mathrm{Al}$ rich system.

Sodalite is also detected in alkaline synthesis at temperatures below $38{ }^{\circ} \mathrm{C}$, but at different times. 7 days for $28^{\circ} \mathrm{C}$ and 28 days for $8{ }^{\circ} \mathrm{C}$. The crystals of sodalite feature slender peaks at a higher temperature, indicating that the crystallinity of this phase rises with increasing temperature.

In Table 3 and Table 4 the zeolite phases existent in the activated ash at 3 days and 28 days at all temperatures are described qualitatively.

A greater activity in the formation of crystals for the CP ash is observed. This can be associated with the greater quantity of alkalis and oxides of calcium present in the starting ash, which can act as nucleation points (15) facilitating the formation of the zeolitic phases. It is noteworthy that in most of the temperatures at 3 and 28 days the formation of the crystalline structures has already been achieved, which indicates that it is the same for intermediate ages. Now, for both ashes, the appearance of zeolite $\mathrm{X}$ is progressive with the curing time, but at low temperature conditions, in all cases below $18^{\circ} \mathrm{C}$.

In the X-ray diffractograms, a halo in the $2 \theta$ position between $20^{\circ}$ and $40^{\circ}$ corresponding to the amorphous phase was observed in both coal ashes. The variation in the position of the point of maximum intensity of the halo at different temperatures and ages of study is shown in Figure 4.

It can be seen that the $\mathrm{CP}$ ash, in all evaluated conditions, always features a greater value of $2 \theta$ with respect to the CT ash. This can be explained by the higher content of calcium oxide present in CP that contributes to modifying the structure of the vitreous siliceous phases, which displaces the halo to higher values, in consonance with what is reported by S. Diamond (16), who found in his research that the maximum angular position of this vitreous halo increased linearly with the calcium content in their samples. It can also be seen that as the temperature increases the halo is displaced towards values greater than $2 \theta$, which is a characteristic of the formation of the gels product of the alkaline activation (13). At $8{ }^{\circ} \mathrm{C}$ the displacement of the angle shows a high variability according to the age of curing, variability that decreases to a higher temperature, hence showing the high incidence of temperature on the development of alkali aluminosilicate gels. At $38{ }^{\circ} \mathrm{C}$ all systems, regardless of the synthesis time, converge to the same value of $2 \theta$, which represents a minimum temperature necessary to form alkali-activated cements in less than 72 hours for these systems (alumina-silicic precursor and $\mathrm{NaOH})$.

Taking the $2 \theta$ position of higher intensity in the halos of both unactivated ashes, as a reference 
TABLE 3. Qualitative phase identification on activated CT ash

\begin{tabular}{|c|c|c|c|c|c|c|}
\hline & & & $8^{\circ} \mathrm{C}$ & $18^{\circ} \mathrm{C}$ & $28^{\circ} \mathrm{C}$ & $38^{\circ} \mathrm{C}$ \\
\hline \multirow[t]{4}{*}{ CT } & Hydroxy-sodalite & 3 days & absent & very poor & present & present \\
\hline & (PDF 00-011-0401) & 28 days & very poor & very poor & present & present \\
\hline & zeolite X & 3 days & absent & absent & absent & absent \\
\hline & (PDF 00-038-0237) & 28 days & very poor & poor & absent & absent \\
\hline
\end{tabular}

TABLE 4. Qualitative phase identification on activated CP ash

\begin{tabular}{|c|c|c|c|c|c|c|}
\hline & & & $8^{\circ} \mathrm{C}$ & $18^{\circ} \mathrm{C}$ & $28^{\circ} \mathrm{C}$ & $38^{\circ} \mathrm{C}$ \\
\hline \multirow[t]{6}{*}{$\mathrm{CP}$} & Hydroxy-sodalite & 3 days & absent & very poor & present & present \\
\hline & & 28 days & very poor & very poor & present & present \\
\hline & zeolite Phi & 3 days & absent & absent & absent & absent \\
\hline & (PDF 00-038-0261) & 28 days & absent & absent & absent & present \\
\hline & zeolite X & 3 days & absent & absent & absent & absent \\
\hline & (PDF 00-038-0237) & 28 days & very poor & present & very poor & very poor \\
\hline
\end{tabular}
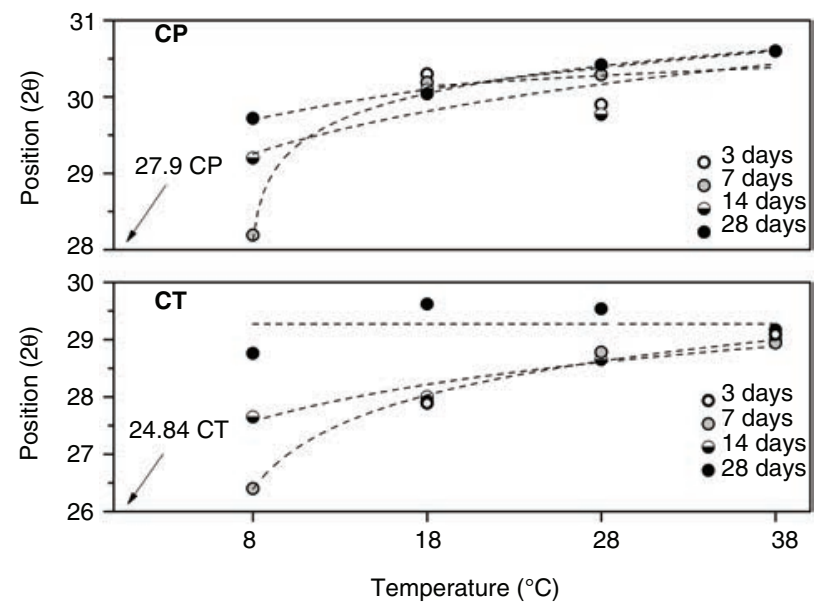

FIGURE 4. Relation between temperature, curing time, and maximum value of the amorphous phase halo of the XRD

$\left(\mathrm{CP}=27.9^{\circ}\right.$ and $\left.\mathrm{CT}=24.84^{\circ}\right)$, it can be noticed that the change is $17 \%$ for $\mathrm{CT}$ and $9.5 \%$ for $\mathrm{CP}$ for a temperature of $38^{\circ} \mathrm{C}$. A major displacement would represent a higher chemical activity in the system. In other words, there is a micro-structural restructuring, which identifies a higher reactivity in CT. This could also be explained by the fact that the halo product of the alkaline synthesis of $\mathrm{CT}$ at temperatures of $8{ }^{\circ} \mathrm{C}$ and 28 days has shifted in position by $16 \%$, which is not far from the characteristics of the amorphous component of the synthesis of the same ash at $38^{\circ} \mathrm{C}$. This same phenomenon occurs in $\mathrm{CP}$, but with only $7 \%$ intensity.

\subsection{Identification by FTIR}

The IR spectrum of both ashes is presented in Figure 5. Zone 1 represents the asymmetric tension

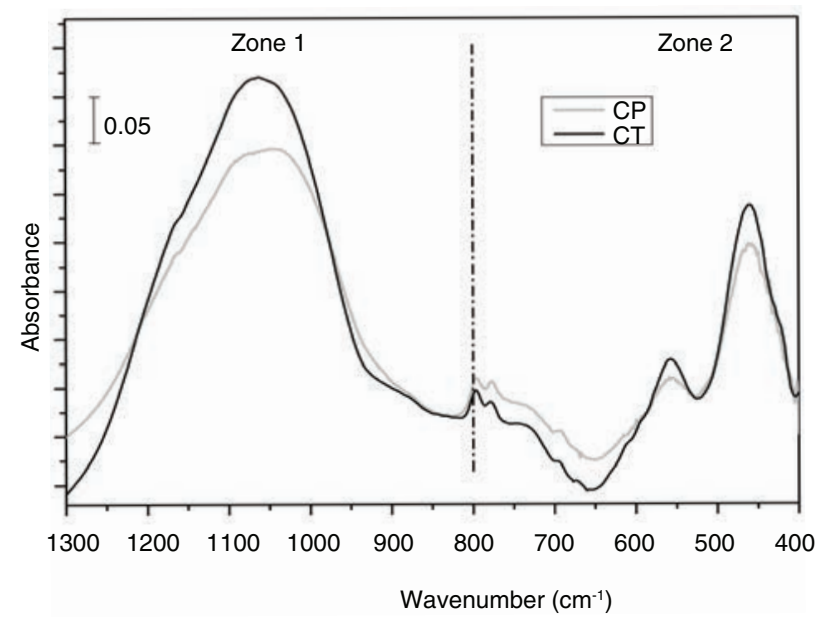

Figure 5. FTIR spectra of both coal ashes

band T-O, which can be (Si-O, Al-O) among 1400$800 \mathrm{~cm}^{-1}$. Zone 2 comprised between $400-800 \mathrm{~cm}^{-1}$ corresponds to the outer vibration bands of the different zeolite-type cyclic structures, which exist in the silicates, and which are formed by the connection of $\mathrm{AlO}_{4}$ and $\mathrm{SiO}_{4}$ tetrahedra through oxygen bridge atoms (17). This area will be of interest for the subsequent analysis of the reaction products of the synthesis of each ash.

In zone $1, \mathrm{CP}$ ash compared to $\mathrm{CT}$, has a slight displacement in the band towards lower values, which may indicate the presence of components with asymmetric T-O-T bonds, which allow a better alkaline synthesis. On the other hand, the high intensity in absorbance in zone 1 for $\mathrm{CT}$ ash compared to $\mathrm{CP}$ can be associated with a greater number of components with symmetrical and asymmetric T-O-T bonds. 
Figure 6 shows, for both coal ashes, the displacement of the asymmetric tension band of the T-O-T bonds, which can be Si-O-Si or Si-O-Al, in the wave number range between $1100 \mathrm{~cm}^{-1}$ and $970 \mathrm{~cm}^{-1}$, with respect to both the temperature and curing time.

Between the two ashes and their activating products at different temperatures, a reduction in wavelength is observed, which has been explained by some researchers as a variation in the chemical structure, as well as in the vitreous structure (7). In the latter case, corresponding to a lower degree of reticulation of the amorphous phase, that is to say, increased amorphicity. Among the activated materials, it can be seen that as the temperature increases, this band moves to lower values with respect to the unactivated ash.

The coal ash in contact with the activator dissolves its vitreous compound and immediately afterward, it precipitates a reaction product, sodium aluminosilicate gel, with a $\mathrm{Si} / \mathrm{Al}$ close to the unity (18-23). As the system is enriched in Al, the band shifts to lower values (7).

The phenomenon is associated with the breakage of the Al-O bonds since in these they break more easily than the $\mathrm{Si}-\mathrm{O}$ bonds. Hence, in this first stage of formation, the first gels are rich in Al.
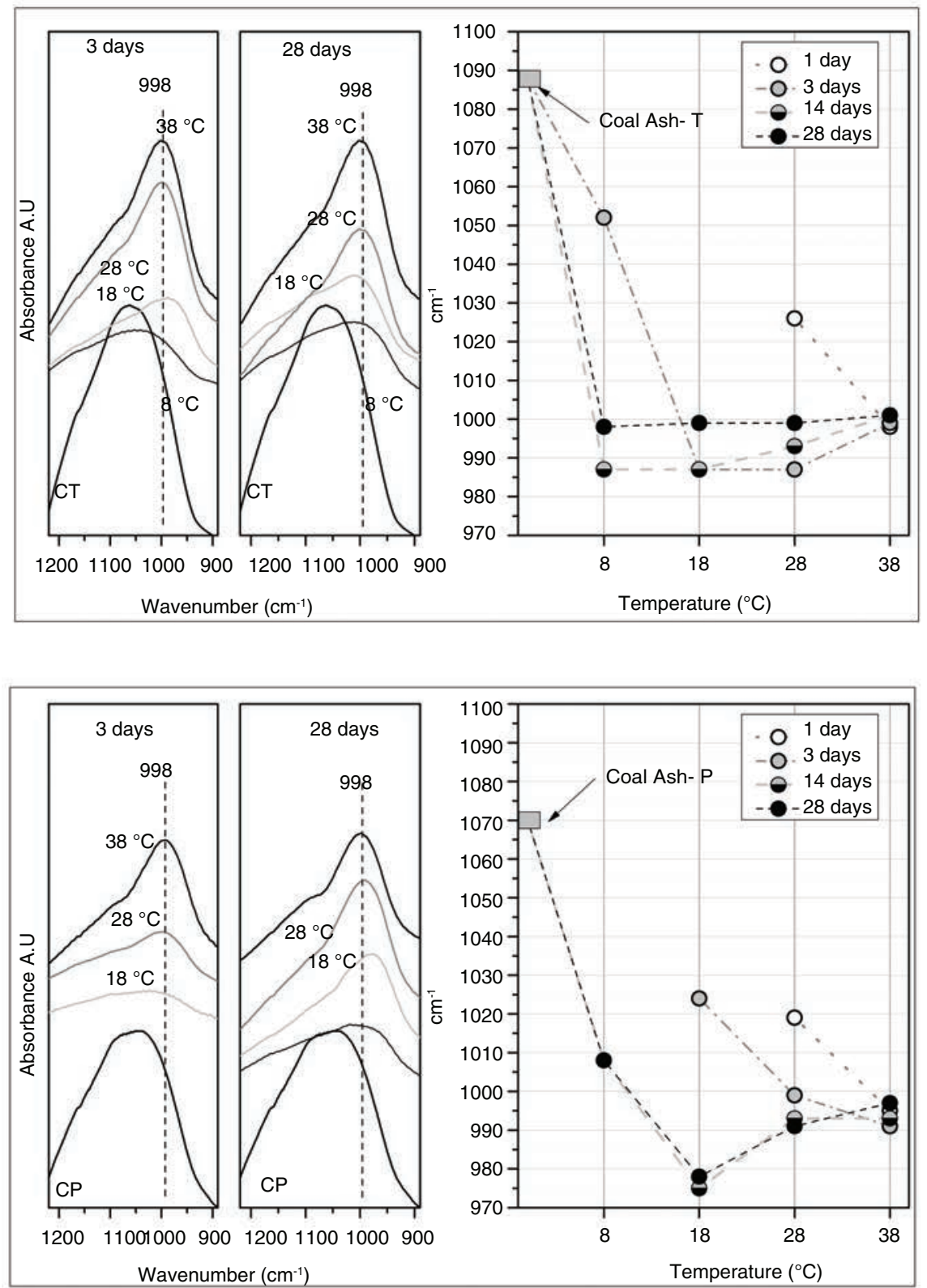

FIGURE 6. Displacement of the band between $1100 \mathrm{~cm}^{-1}$ and $970 \mathrm{~cm}^{-1}$ of the FTIR depending on temperature and time for study ashes 
After the system evolves presenting a displacement of the IR spectrum in the asymmetric tension band at values higher than $998 \mathrm{~cm}^{-1}$. This is phenomenon is due to the fact that the system becomes enriched in Si (19). Accordingly, the properties at early ages are governed by gels rich in $\mathrm{Al}$ and at final ages, they are governed by gels rich in $\mathrm{Si}$.

As in X-ray diffraction, the formation of the gel is strongly affected at temperatures below $28^{\circ} \mathrm{C}$. In both ashes, the systems tend to converge to similar values in the tension bands associated with the formation of the (T-O-T) gel, indicating that the characteristics of the gel can be very similar, although the formation process is strongly dependent on both temperature and time. This can be observed in the change of both the 2 Theta (Figure 4 ) as in the wave number (Figure 6) for each isotherm. Where the abscissa for progressive temporal events is very variable at low synthesis temperatures. Nevertheless, in periods of prolonged times, the values are usually adjusted to those obtained at temperatures of $38^{\circ} \mathrm{C}$.

In the spectral range of Figure 7, the appearance of some bands is observed when the coal ash is activated at different temperatures. In zone 2 , the vibration bands, which are called secondary structural units (SBU) (24), provide information on the environment of the tetrahedrons in two-dimensional or three-dimensional structures (Links of tetrahedra $\mathrm{TO}_{4}, \mathrm{~T}: \mathrm{Si}, \mathrm{Al}$ ), as well as the type of ring (Single or double). The increase in the number of units of the ring displaces the band of vibrations towards lower frequencies: $720-700 \mathrm{~cm}^{-1}$ for rings of three units, $650 \mathrm{~cm}^{-1}$ for 4 units, $620-600 \mathrm{~cm}^{-1}$ for 6 units.

For most of the evaluated conditions of time and temperature, although not for $8{ }^{\circ} \mathrm{C}$ at ages less than 3 days, the presence of bands at $720 \mathrm{~cm}^{-9}$ is observed for the two ashes that account for new products of characteristic synthesis of $\mathrm{Al}_{\mathrm{T}}-\mathrm{O}$, bonds associated with hydroxisodalite structures rich in aluminum. This is in accordance with the mineralogical analysis by XRD. Increases in bandwidth from 560 to 573 $\mathrm{cm}^{-\mathrm{r}}$ are associated with faujasite (25). This occurs with greater frequency in samples cured at $18^{\circ} \mathrm{C}$.

\subsection{Microcalorimetric Evaluation}

The calorimetric response points out two peaks, as shown, by way of example, in Figure 8 for the $\mathrm{CP}$ ash at $28{ }^{\circ} \mathrm{C}$. The first peak is mainly by the energy released in the dissolution of the vitreous phase of the ash upon contact with the activating agent. And the second peak, by the growth and precipitation of gels and mineralogical phases of the reaction products, which begin to be reorganized locally in networks of greater length. Between these two peaks, there is a significant reduction in the heat flow that gives rise to a dormant period. The area under the curve of the microcalorimetric signal represents the total energy released over time due to both the physical and chemical processes, which are carried out during the alkaline activation (gray line Figure 8), indicating the kinetic behavior, as well as the degree of reaction that the ashes exhibit.

Figure 9 shows the temperatures $18{ }^{\circ} \mathrm{C}, 28{ }^{\circ} \mathrm{C}$, and $38^{\circ} \mathrm{C}$ and the accumulated energy for both $\mathrm{CT}$ and $\mathrm{CP}$ ashes. It is worth noticing that regardless of the synthesis temperature the released energy product of the activation can be equivalent in different temporal periods. Thus, indicating that the alkaline synthesis of $\mathrm{CT}$ at $38^{\circ} \mathrm{C}$ takes approximately 3 days to release $225 \mathrm{~J} / \mathrm{g}$, at $28^{\circ} \mathrm{C}$, it takes 13.7 days, and at $18^{\circ} \mathrm{C}$, it takes 25 days to release the same amount of energy. In the case of the alkaline synthesis of $\mathrm{CP}$, it releases $125 \mathrm{~J} / \mathrm{g}$ in 3 days at $38^{\circ} \mathrm{C}$, in 12.5 days at $28^{\circ} \mathrm{C}$, and in 18.75 days at $18^{\circ} \mathrm{C}$.

The difference in microcalorimetric response of both ashes is due, among other causes, to the particle size, chemical composition, amount of unburned coal, and percentage of amorphous phase, characteristics, which are described above. Regardless of the temperature, the energy released from the activation of the $\mathrm{CT}$ ash is greater than that of the $\mathrm{CP}$ ash. And if the temperature increases, the amount of energy released does too, which indicates that the reactivity of $\mathrm{CT}$ is greater than the reactivity of the CP. The time for the release of energy decreases substantially as the temperature increases. For instance, to release $100 \mathrm{~J} / \mathrm{g}$ the $\mathrm{CT}$ ash requires 170 hours at $18^{\circ} \mathrm{C}$, whereas at $38^{\circ} \mathrm{C}$, it only requires 7.5 hours. This is a phenomenon, which is linked to the increase of the ionic mobility of the system with temperatures, as it has been stated by researches like Bing-hui et al. (26), where by means of electrochemical impedance at temperatures between $20^{\circ} \mathrm{C}$ and $80^{\circ} \mathrm{C}$, they evaluated the reaction rates, polymerization, and precipitation processes of the reaction products; finding a direct relation between electrical conductivity associated with these phenomena, as well as the increase of the temperature.

\subsection{Mechanical analysis}

For each temperature, compressive strength of paste specimens was evaluated at ages of $1,3,7,14$ and 28 days. The loading rate was $300 \mathrm{~N} / \mathrm{s}$ in compliance with ASTM C349 standards. Figure 10 shows the results.

It is clear that the mechanical response of the CT ash is greater in all cases than the $\mathrm{CP}$ ash, which can be explained by their chemical, particle size and crystallographic differences (content of amorphous phases). The incidence of temperature and curing time on obtaining the mechanical strength is observed. The two ashes, at the lowest temperature, do not show resistance before 7 days. When they are taken to $38^{\circ} \mathrm{C}$ for 3 days, they have already reached more than $30 \%$ of the highest resistance obtained. 

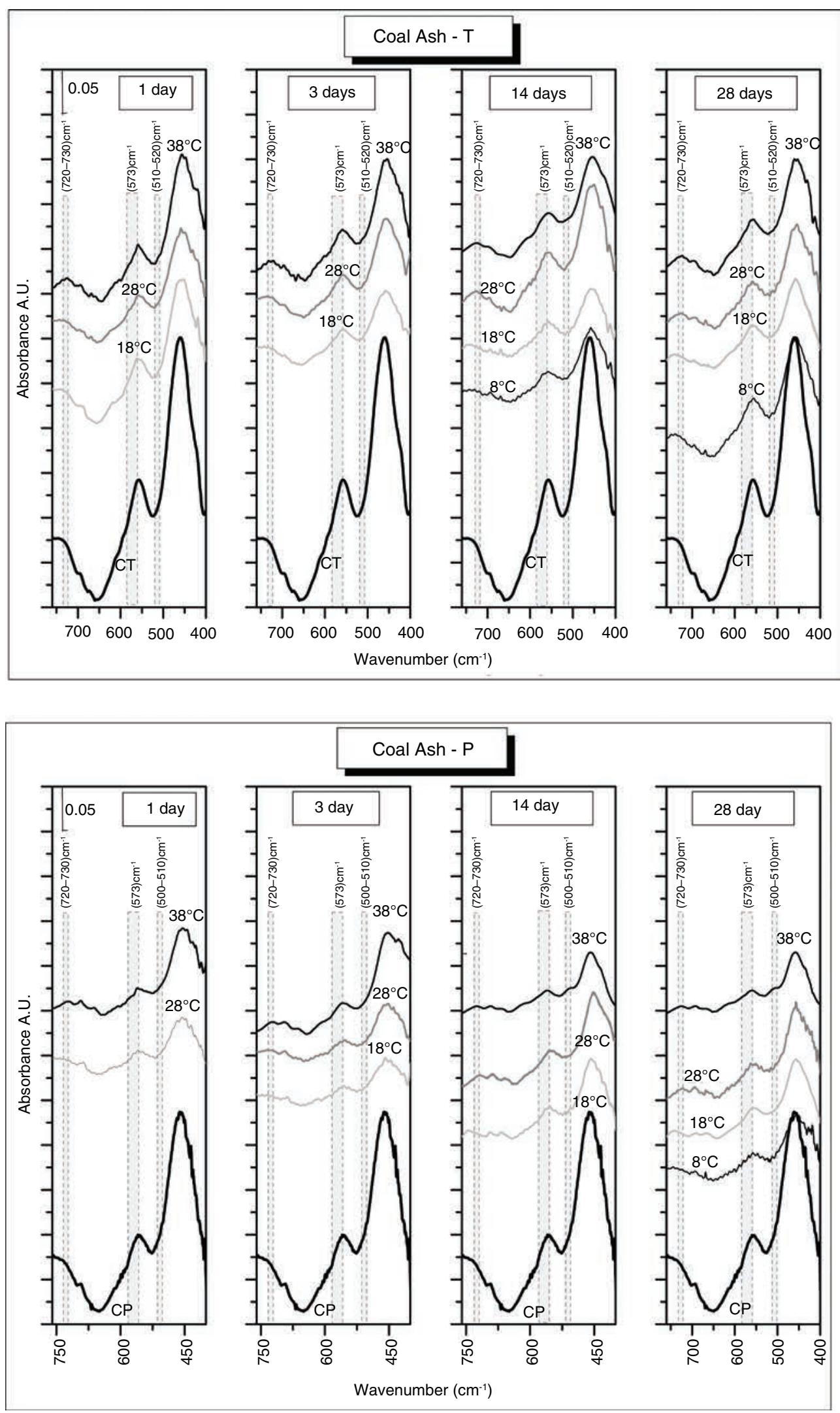

FIGURE 7. FTIR spectra in zone 2 for both ashes and their activation products at different temperatures and curing ages 


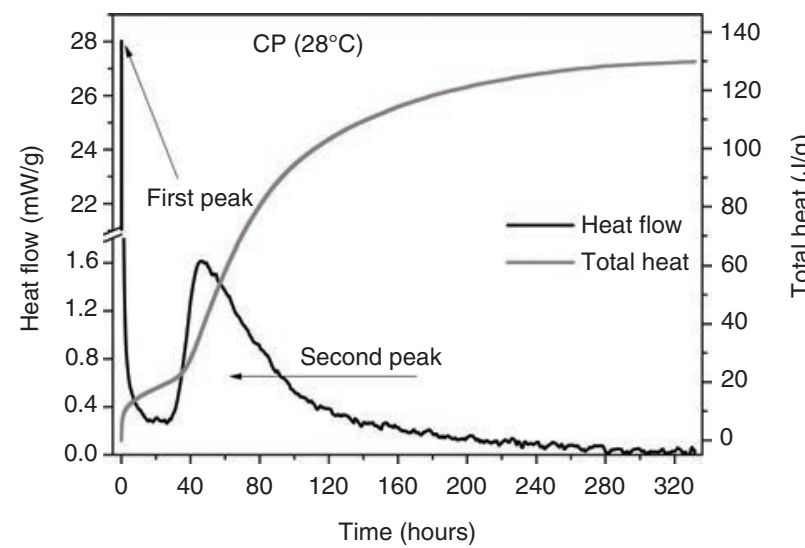

Figure 8. Microcalorimetry at $28^{\circ} \mathrm{C}$ for $\mathrm{CP}$ ash

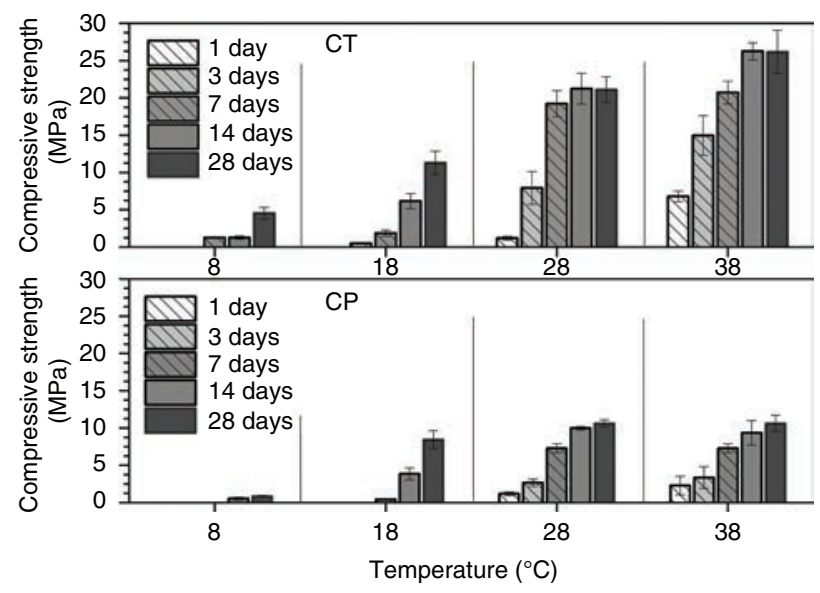

FIGURE 10. Compressive strength of alkali-activated $\mathrm{CT}$ and CP ashes at $8^{\circ} \mathrm{C}, 18^{\circ} \mathrm{C}, 28^{\circ} \mathrm{C}$, and $38^{\circ} \mathrm{C}$

\section{DISCUSSION}

According to the results obtained in this research, it is possible to state that it is feasible to activate coal ash at a room temperature, reaching compressive strengths above $20 \mathrm{MPa}$. But as much or more important than the temperature, in times of synthesis less than 28 days, are the characteristics of the starting ash, since better physical and chemical conditions of the ash guarantees a greater available energy to be released during the alkaline activation and accordingly, a better performance of the cement is obtained (27)(28).

By observing the mechanical response of the alkali-activated ashes (Figure 10), the influence of the ash type is clear, which is determined by parameters, such as the reactive silica and alumina contents, amorphous phase content, particle-size distribution, and unburned coal amounts (LOI). In other words, the reaction speed depends clearly on their physical and chemical characteristics (20)(27)(29), without ruling out the importance of temperature.

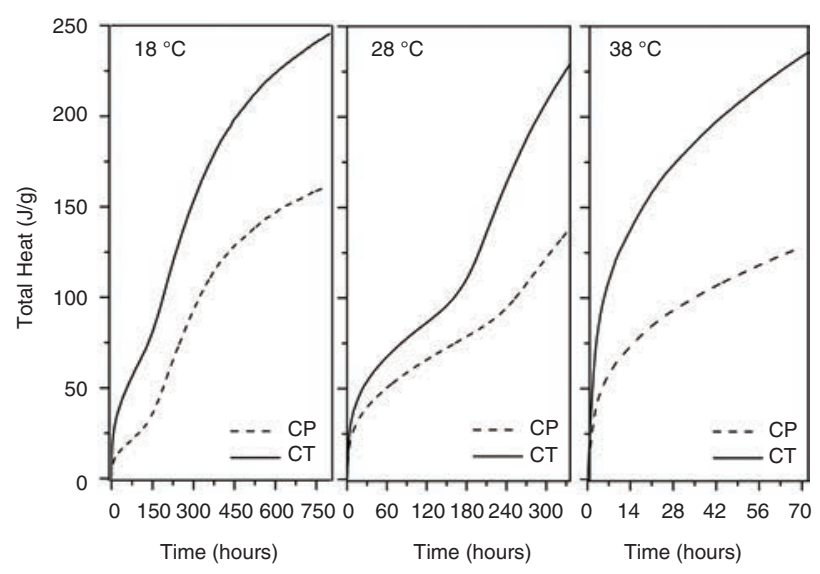

FIgURE 9. Microcalorimetry of accumulated energy at $18{ }^{\circ} \mathrm{C}$, $28^{\circ} \mathrm{C}$, and $38^{\circ} \mathrm{C}$ for $\mathrm{CT}$, and $\mathrm{CP}$ ashes

In all the above parameters, the $\mathrm{CT}$ ash features the best conditions. It was evidenced that a high content of silica and alumina affects the crystallization rate and formation of zeolites, and encourages the formation of silicon-rich alkali aluminosilicate type gels (19) as it was the case in CT. A higher presence of amorphous phase in the raw materials increases the mechanical performance of the cements manufactured with them. This is because it guarantees the availability of dissolved species for the formation of monomers and subsequent growth of the polymer network $(19,21,22)$. The unburned coal contents (LOI) in the ash are particles, which are not part of the activation process, that is to say, unreacted particles, which increase porosity $(19,26,27)$ and this largely explains the poor performance of the cement obtained with CP ash. The particle size not only affects the properties in the fluid state of the cement, but it also affects the ash reactivity (19) (29) by increasing the area of wetting between the ash and the activator, which results in an increase in kinetics reaction and increased resistance $(27,29)$ (30). The presence of metals (calcium and sodium) in the ash affects its degree of reaction $(31,32)$. Their inclusion in the amorphous network modifies their minimal energy state by decreasing dissolution and accelerating the diffusion and nucleation mechanisms $(31,33,34)$.

\section{CONCLUSIONS}

From the results found in the study of the activation of coal ash with sodium hydroxide, at temperatures from $8{ }^{\circ} \mathrm{C}$ up to $38^{\circ} \mathrm{C}$, the most relevant conclusions are the following:

That regardless of temperature, the early stages of the activation process are governed by the physical and chemical characteristics of coal ash used, such as: $\mathrm{SiO}_{2} / \mathrm{Al}_{2} \mathrm{O}_{3}$ molar ratio, amorphous phase percentage, unburned coal content and particlesize distribution, which significantly affect the 
performance of the alkaline activation process. For these reasons, the pastes made with $\mathrm{CT}$ ash showed better mechanical results than those made with $\mathrm{CP}$, in the curing times analyzed.

It is possible to achieve the synthesis of alkaliactivated cement from coal ash at temperatures of $8{ }^{\circ} \mathrm{C}$, although with very poor compressive strength results in the evaluation period of time, due to the slow development of chemical reactions.

For the ashes studied, especially for CT, alkali activation is feasible from $28^{\circ} \mathrm{C}$ because very acceptable compressive strength results (above $20 \mathrm{MPa}$ ) are obtained. This is because the speed at which the heat transfer is carried out must be such so that the highest degree of reaction of the ash is guaranteed in the shortest time possible and this was achieved satisfactorily in this study around $28^{\circ} \mathrm{C}$

From microcalorimetric tests, it can be concluded that regardless of the synthesis temperature, the released energy, product of the activation, can be equivalent in different temporal periods. Furthermore, that regardless of the temperature, the energy released from the activation of the CT ash is greater than that of $\mathrm{CP}$ ash thanks to its physicalchemical characteristics.

The alkali-activated coal ash $\mathrm{T}$ at $18{ }^{\circ} \mathrm{C}$ did not show formation of zeolites until the age of 28 days, which allows to affirm that the zeolites require a higher temperature for their appearance at early ages.

Through the XRD and FTIR techniques, it was possible to determine that the different gels show similar characteristics, although with a slight tendency to present crystals as a result of the alkaline synthesis with more complex systems for temperatures below $18{ }^{\circ} \mathrm{C}$, this is attributed to the systems reacting 10 to 20 times slower to generate $100 \mathrm{~J} / \mathrm{g}$ when compared to temperatures of $38^{\circ} \mathrm{C}$. However, for the conditions evaluated, it is suggested that the effect of the temperature on the simple systems $(\mathrm{NaOH}+$ precursor $)$ is of a temporary nature.

\section{REFERENCES}

1. Palomo, A.; Krivenko, P.; García-Lodeiro, I.; Kavalerova, E.; Maltseva, O.; Fernández-Jiménez, A. (2014) A review on alkaline activation : new analytical perspectives. Mater. Construcc. 64 [315], 1-24. https://doi.org/10.3989/mc.2014.00314.

2. Torres-carrasco, M.; Palomo, J.G.; Puertas, F. (2014) Sodium silicate solutions from dissolution of glass wastes. Statistical analysis. Mater. Construcc. 64 [314], 1-14. https://doi.org/10.3989/mc.2014.05213.

3. Mejía, JM.; Mejía de Gutiérrez, R.; Puertas, F. (2013) Rice husk ash as a source of silica in alkali-activated fly ash and granulated blast furnace slag systems. Mater. Construcc. 63 [311], 361-75. https://doi.org/10.3989/mc.2013.04712.

4. Temuujin, J.; Minjigmaa, A.; Bayarzul, U; Kim, D.S. Lee, S. Ho.; Lee, H.J.; Ruescher, C.H.; MacKenzie, K.J.D. (2017) Properties of geopolymer binders prepared from milled pond ash. Mater. Construcc. 67 [328], 1-11. https:// doi.org/10.3989/mc.2017.07716.

5. Luna, Y.; Cornejo, A.; Leiva, C.; Vilches Arenas, L.F.; Fernández Pereira, C. (2015) Properties of fly ash and metakaolín based geopolymer panels under fire resistance tests. Mater. Construcc. 65 [319], 1-8. https://doi. org/10.3989/mc.2015.06114.

6. Palomo, A.; Grutzeck, M.W.; Blanco, M.T. (1999) Alkali-activated fly ashes A cement for the future. Cem. Concr. Res. 29 [8], 1323-9. https://doi.org/10.1016/ S0008-8846(98)00243-9.

7. Al-Majidi, M.H.; Lampropoulos, A.; Cundy, A.; Meikle, S. (2016) Development of geopolymer mortar under ambient temperature for in situ applications. Constr. Build. Mater. 120, 198-211. https://doi.org/10.1016/j.conbuildmat.2016.05.085.

8. Mustafa Al Bakria, A.M.; Kamarudin, H.; Bin Hussain, M.; Khairul Nizar, I.; Zarina, Y.; Rafiza, A.R. (2011) The effect of curing temperature on physical and chemical properties of geopolymers. Phys. Procedia. 22, 286-91. https://doi. org/10.1016/j.phpro.2011.11.045

9. Temuujin, J.; Williams, R.P.; Van Riessen, A. (2009) Effect of mechanical activation of fly ash on the properties of geopolymer cured at ambient temperature. J. Mater. Process. Technol. 209 [12-13], 5276-80. https://doi.org/10.1016/j. jmatprotec.2009.03.016.

10. Davidovits, J. (1980) Ceramic-ceramic composite material and production method. United States Patent. 1-6.

11. Chithiraputhiran, S.; Neithalath, N. (2013) Isothermal reaction kinetics and temperature dependence of alkali activation of slag, fly ash and their blends. Constr. Build. Mater. 45, 233-42. https://doi.org/10.1016/j. conbuildmat.2013.03.061.

12. Cioffi, R.; Maffucci, L.; Santoro, L. (2003) Optimization of geopolymer synthesis by calcination and polycondensation of a kaolinitic residue. Resour. Conserv. Recycl. 40 [40], 27-38. https://doi.org/10.1016/S0921-3449(03)00023-5.

13. Provis, J.L.; Lukey, G.C.; Van Deventer, J.S.J. (2005) Reviews. Do geopolymers actually contain nanocrystalline zeolites? a reexamination of existing results. Chem. Mater. 17 [12], 3075-85. https://doi.org/10.1021/cm050230i

14. Rovnaník, P. (2010) Effect of curing temperature on the development of hard structure of metakaolin-based geopolymer. Constr. Build. Mater. 24 [7], 1176-83. https://doi. org/10.1016/j.conbuildmat.2009.12.023

15. Hoyos-Montilla, Ary A.; Puertas, F.; Tobón, Jorge I. (2018) Microcalorimetric study of the effect of calcium hydroxide and temperature on the alkaline activation of coal fly ash. J. Therm. Anal. Calorim. 131 [3], https://doi.org/10.1007/ s10973-017-6715-4

16. Diamond, S. (1983) On the glass present in low-calcium and in high-calcium flyashes. Cem. Concr. Res. 13 [4], 45964. https://doi.org/10.1016/0008-8846(83)90002-9.

17. Mozgawa, W.; Sitarz, M. (2002) Vibrational spectra of aluminosilicate ring structures. J. Mol. Struct. 614 [1-3], 273-9. https://doi.org/10.1016/S0022-2860(02)00261-2

18. García Lodeiro, M.I. (2008) Compatibilidad de geles cementantes C-S-H y N-A-S-H. Estudios en muestras reales y en polvos sintéticos. Thesis $\mathrm{PhD}$, (2008).

19. Criado, M.; Fernández-Jiménez, A.; Palomo, A. (2007) Alkali activation of fly ash: Effect of the $\mathrm{SiO}_{2} / \mathrm{Na}_{2} \mathrm{O}$ ratio : Part I: FTIR study. Microporous Mesoporous Mater. 106 [1-3], 180-91. https://doi.org/10.1016/j.micromeso.2007.02.055.

20. Van Jaarsveld, J.G.S.; Van Deventer, J.S.J.; Lukey, G.C. (2003) The characterisation of source materials in fly ashbased geopolymers. Mater Lett. 57 [7], 1272-80. https:// doi.org/10.1016/S0167-577X(02)00971-0.

21. Palomo, A.; López de la Fuente, J.I.; (2003) Alkali-activated cementitous materials: Alternative matrices for the immobilisation of hazardous wastes - Part I. Stabilisation of boron. Cem. Concr. Res. 33 [2]:281-8. https://doi.org/10.1016/ S0008-8846(02)00963-8.

22. Fernández-Jiménez, A.; Palomo, A. (2003) Characterisation of fly ashes. Potential reactivity as alkaline cements. Fuel. 82 [18],2259-65.https://doi.org/10.1016/S0016-2361(03)00194-7.

23. Lee, W.K.W.; Van Deventer, J.S.J.; (2003) Use of infrared spectroscopy to study geopolymerization of heterogeneous amorphous. Aluminosilicates. Langmuir. 19 [21], 8726-34. https://doi.org/10.1021/la026127e.

24. Fernández-Jiménez, A.; Palomo, A. (2005) Mid-infrared spectroscopic studies of alkali-activated fly ash structure. 
Microporous Mesoporous Mater. 86 [1-3], 207-14. https:// doi.org/10.1016/j.micromeso.2005.05.057

25. Mozgawa, W.; Król M.; Barczyk, K. (2011) FT-IR studies of zeolites from different structural groups. Chemik. 65 [7], $671-4$.

26. Mo, B.H.; Zhu, H.; Cui, X.M.; He, Y.; Gong, S.Y. (2014) Effect of curing temperature on geopolymerization of metakaolin-based geopolymers. Appl. Clay Sci. 99, 144-8. https://doi.org/10.1016/j.clay.2014.06.024.

27. Soutsos, M.; Boyle, A.P.; Vinai, R.; Hadjierakleous, A.; Barnett, S.J. (2016) Factors influencing the compressive strength of fly ash based geopolymers. Constr. Build. Mater. 110, 355-68. https://doi.org/10.1016/j. conbuildmat.2015.11.045.

28. Palomo, A.; Criado, M. (2006) Alkali activated fly ash binders. A comparative study between sodium and potassium activators. Mater. Construcc. 281 [56], 51-65. https:// doi.org/10.3989/mc.2006.v56.i281.92.

29. Kumar, R.; Kumar, S.; Mehrotra, S.P. (2007) Towards sustainable solutions for fly ash through mechanical activation. Resour. Conserv. Recycl. 52 [2], 157-79. https://doi. org/10.1016/j.resconrec.2007.06.007
30. Kovalchuk, G.; Palomo, A.; Fernández-Jiménez, A. (2008) Alkali-activated fly ash. Relationship between mechanical strength gains and initial ash chemistry. Mater. Construcc. 58 [291], 35-52. https://doi.org/10.3989/ mc.2008.v58.i291.101.

31. Diaz, E.I.; Allouche, E.N.; Eklund, S. (2010) Factors affecting the suitability of fly ash as source material for geopolymers. Fuel. 89 [5], 992-6. https://doi.org/10.1016/j. fuel.2009.09.012.

32. Izquierdo, M. (2016) Contributions to the study of porosity in fly ash-based geopolymers. Relationship between degree of reaction, porosity and compressive strength. Mater. construcc. 66 [324], 1-14. https://doi.org/10.3989/ mc.2016.10215.

33. Messina, F.; Ferone, C.; Colangelo, F.; Cioffi, R. (2015) Low temperature alkaline activation of weathered fly ash: Influence of mineral admixtures on early age performance. Constr. Build. Mater. 86, 169-77. https://doi.org/10.1016/j. conbuildmat.2015.02.069.

34. Fernandez-Jiménez, A.; Puertas, F. (1997) Alcali-activated slag cements: kinetic studies. Cem. Concr. Res. 27 [3], 35968. https://doi.org/10.1016/S0008-8846(97)00040-9 